\title{
Dossiê Tibete: análise dos conflitos sino-tibetanos.
}

\section{Ana Paula Lopes Ferreira1}

\section{RESUMO}

Os conflitos entre China e Tibete vêm de um longo processo histórico e desde 1949, quando ocorre a ocupação chinesa vem ganhando destaque internacional. Desse modo o texto pretende analisar o conflito através do modelo de análise de Galtung em nível estatal, regional e global.

Palavras-chave: Conflitos; Tibete; China.

No dia 11 de abril de 2013 o líder espiritual tibetano Dalai Lama² fez declarações sobre as decorrentes autoimolações de monges tibetanos, afirmando que "os tibetanos que cometeram suicídio para escapar da tortura e prisões na China não são loucos" ${ }^{3}$. A declaração do Dalai Lama faz resurgir na mídia a questão dos conflitos entre a China e o Tibete que, desde 1949, vem sofrendo com a ocupação chinesa em seu território. Além da República Popular da China estar sob o controle de seu sistema político administrativo, ainda é tida como responsável pela destruição da cultura tibetana: proibindo o ensino do idioma tibetano nas escolas e impondo o chinês como idioma oficial dentro do Tibete; impedindo o deslocamento de nômades; e destruindo seus mosteiros.

Os diversos relatos de abusos cometidos pelo governo chinês em ações de repressão às manifestações contrárias à ocupação chinesa no Tibete, bem como pela atuação e representatividade do Dalai Lama no cenário internacional, levam a procura por um maior entendimento dos conflitos ocorridos na região. Desse modo o presente artigo tem como objetivo analisar o conflito sino-tibetano. Ao analisar o conflito em

\footnotetext{
${ }^{1}$ Mestranda do Programa de Pós-Graduação em Ciência Política da Universidade Federal do Paraná.

2 Dalai Lama, líder espiritual tibetano exilado na Índia.

${ }^{3}$ Cf. http://g1.globo.com/mundo/noticia/2013/04/tibetanos-se-imolam-porque-estao-desesperados-dizdalai-lama.html.
} 
âmbito estatal é preciso levar em conta que quem está sendo contestado pelos tibetanos é o governo chinês e não o Estado chinês propriamente.

Os sucessivos governos que comandaram a China desde 1950 - quando ocorreu a invasão no Tibete - tem a sua percepção política voltada para o socialismo/comunismo. Essa vertente política defende um Estado sem intervenção religiosa de nenhuma espécie, sem eleições democráticas e prega uma igualdade econômica entre os seus nacionais. Essas, dentre outras características - exceto eleições democráticas, vão contra o sistema político tibetano que consistia num regime político teocrático e, até mesmo, contra o sistema político chinês que não vê os tibetanos como iguais, restringindo o acesso da população tibetana à saúde e à educação. Desde a ocupação chinesa está proibido nas escolas o ensino da cultura e do idioma tibetano.

Em âmbito regional, a contenda afeta diretamente as relações da China com a Índia. Desde a ocupação chinesa a Índia vem apoiando a causa tibetana. Além do Estado indiano abrigar o governo tibetano em exílio e o XIV Dalai Lama, buscou intervir diplomaticamente no conflito a partir de tentativas de diálogos com a China, porém sem resultados significativos. Os demais Estados da região se mantêm em posição de neutralidade, não interferindo na questão sino-tibetana, seja por falta de recursos bélico-econômicos que façam frente às potencialidades chinesas, ou pelo quadro de dependência desses países em relação aos recursos naturais essenciais sob controle chinês - como a água que nasce em solo tibetano, mas que está sob controle chinês.

Em um nível de análise global, que verifica os interesses geopolíticos externos em relação ao conflito, leva-se em consideração a presença de tropas chinesas e de mísseis intercontinentais instalados no Tibete. Esse cenário representa não apenas uma afirmação de controle do território tibetano pelo governo chinês, como uma ameaça aos demais países do continente, principalmente à Rússia e à Índia. Uma eventual renúncia da China ao 'seu direito sobre o território tibetano', diminuiria futuras possibilidades de haver invasões territoriais além-fronteiras e eventuais agraves com demais Estados próximos.

O conflito chinês-tibetano, visto da perspectiva de Galtung4, pode ser considerado como um conflito de violência direta e cultural ${ }^{5}$. Direta por causa das

\footnotetext{
${ }^{4}$ Modelo de Galtung presente no livro: (2005) Contemporary Conflict Resolution.
} 
inúmeras mortes ocorridas desde a ocupação chinesa até os dias atuais, provocadas em sua grande maioria pela repressão do governo chinês às inúmeras manifestações contra o seu modelo de governo, resultando em violações aos direitos dos tibetanos. A violência cultural está presente na percepção do governo chinês e de sua população - em sua maioria da etnia han - em relação aos tibetanos, que são colocados em situação de inferioridade dentro da área de domínio chinês, não tendo os mesmo direitos que os chineses.

De acordo com o modelo de escalada e de-escalada, o conflito está na fase de violência, havendo represarias por parte do governo chinês para conter os protestos contra a ocupação da região. Porém, antes passou pela fase de guerra na invasão chinesa na década de 1950, quando os tibetanos tentaram defender o seu território da invasão. Sobre a classificação dos conflitos no Tibete, pode-se dizer que, atualmente o conflito é assimétrico, pois envolve o Estado chinês e a etnia tibetana, havendo assim uma disparidade de poder bélico e militar entre as partes. Atualmente o conflito é manifesto, mas historicamente sempre oscilou entre latente e manifesto. É um conflito de alta intensidade para ambas as partes envolvidas, pois envolve a questão territorial.

Para a China a região é essencial do ponto de vista econômico e estratégico, o solo tibetano é rico em minérios. É dentro do Tibete que nasce os rios mais importantes para o abastecimento de água doce da Ásia oriental. Além da área possuir uma imensa reserva ambiental pouco explorada, abriga ainda uma variedade imensa de plantas usadas na medicina chinesa - a fitoterapia - que tem como base o uso de plantas da região. Em relação à questão militar e sua segurança, como já visto, encontram-se na região tibetana mísseis intercontinentais - inclusive nucleares - além da forte presença do exército chinês. Além do controle dos recursos naturais, uma outra explicação para o posicionamento contrário do governo chinês à independência do Tibete seria o efeito dominó na secessão político-territorial do Estado chinês. A independência de uma região levaria a uma série de reivindicações de independência em todo território, já que o Estado chinês é composto por inúmeras etnias em diversas províncias.

50 modelo desenvolvido pelo matemático e sociólogo Johan Galtung, consiste no triângulo da violência, que representa a relação entre os três tipos de violência, definidas em sua teoria como: violência direta, violência estrutural e violência cultural. 
Para os tibetanos a questão territorial é fundamental, pois é o território que define seu país. Sendo necessário o controle da região para a preservação da sua cultura, e também para garantir que a exploração das riquezas naturais beneficie a população tibetana, não somente os chineses como ocorre atualmente. Quanto à solubilidade, o conflito pode ser considerado litigioso, já que há a possibilidade de resolução pacífica, sem chegar à guerra, a partir do momento que o governo da China garanta a autonomia da região, e os tibetanos aceitem esse status.

Analisando os níveis do conflito sino-tibetano, pode-se concluir que este se encontra em posições fixas. 0 governo chinês não aceita negociar a questão tibetana, o vendo como parte territorial do Estado chinês. Desse modo tendo direitos sobre a região, o governo chinês pode controlar os recursos naturais, como a água e explorar a biodiversidade local. Do lado tibetano há dois posicionamentos distintos, de um lado o grupo a favor da autonomia, que deseja a autonomia plena da região, assim como os seus direitos e liberdades, mas sob o Estado chinês. Já o grupo a favor da independência espera que a ocupação chinesa acabe, e o Tibete volte ao seu modelo político teocrático tendo o Dalai Lama como líder político e religioso.

\section{Referências bibliográficas}

ALMEIDA, Carmem Lícia. O domínio chinês sobre o Tibete. Rev. bras. polít. int. vol.43 no.1 Brasília Jan./June 2000.

Disponível

em:

http://www.scielo.br/scielo.php?pid=S003473292000000100008\&script=sci_artte xt >. Acesso em: 20 mai. 2012.

ARANTES, José Tadeu. Olimpíadas ameaçadas. Le Monde Diplomatique Brasil, 2008. Disponível em:

http://www.diplomatique.org.br/artigo.php?id=181\&PHPSESSID=3a3235b1203f3 6038662bd8133fd859a >. Acesso em: 07 jun. 2012.

CENTRO DE CULTURA TIBETANA. Disponível em:

http://www.culturatibetana.com.br/conheca-o-tibete/geografia.html >. Acesso em: 26 mai. 2012. 
DALAI LAMA. Disponível em: http://www.dalailama.org.br/home/>. Acesso em: 26 mai. 2012.

FARRER-HALLS, Gill. Dalai Lama: sua vida, seu povo e sua visão. São Paulo, editora Madras. 2003.

G1MUND0. Disponível em: http://g1.globo.com/mundo/noticia/2013/04/tibetanos-seimolam-porque-estao-desesperados-diz-dalai-lama.html. Acesso: em 22 abril 2013.

MARCUCCI, Cynthia M. O que é a questão sino-tibetana? Disponível em: < http://www.fasm.edu.br/interrelacoes/33/004.html >. Acesso em: 20 mai. 2012.

RAMSBOTHAM, Oliver; WOODHOUSE, Tom; HUGH, Mial. Contemporary Conflict Resolution. 2nd ed. Cambridge, Malde: Polity, 2007

SEIDE, Patrícia. O Tibete e seus avanços em direção à democracia. Conjuntura Internacional, 2010. Disponível em: < http://www.pucminas.br/imagedb/conjuntura/CNO_ARQ_NOTIC20100920143405 .pdf?PHPSESSID=6f637a02ea0df6ebea8ae3824c49cba6 >. Acesso em: 26 mai. 2012.

TIBETE, Brasil. Disponível em: < www.brasiltibet.org.br/biblioteca/relatoaonu.html >. Acesso em: 26 mai. 2012. 